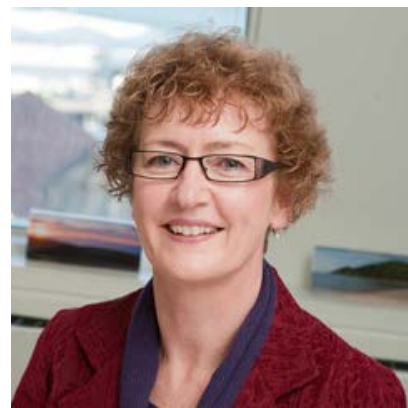

\title{
DO MANAGERS CARE?
}

\section{Jane Bryson and Urs Daellenbach}

\author{
School of Management \\ Victoria University of Wellington
}

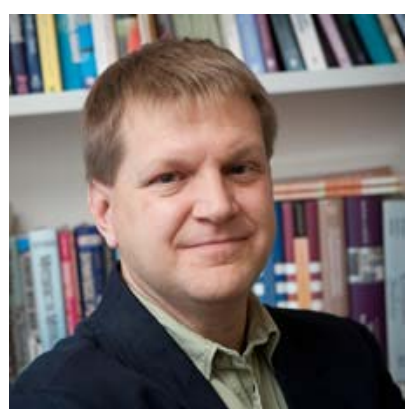

\begin{abstract}
Addicts of reality television who are also interested in labour, employment and work will no doubt have watched "Undercover Boss" in a combination of stunned disbelief and awe as formerly unconnected managers are exposed to a taste of workplace reality when they take on the role of an entry level worker in their own organisation. What the best of these undercover bosses discover is a measure of empathy with the circumstances of their workers and other stakeholders in their businesses. Surprisingly empathy is a factor which has received relatively little attention in business and workplace research. In recent research we conducted in New Zealand SMEs on another topic we identified fascinating examples of managerial empathy impacting the organisation's business practices, strategy and behaviour towards workers, customers, suppliers and others. In this paper we report these examples of managerial empathy and discuss their implications for managers, workplaces and future research.
\end{abstract}

\section{Introduction}

Popular US television programme "Undercover Boss” has received mixed reactions for its covert placement of chief executives into the lowest paid front line positions in their own company. It is a lesson in enforced empathy as these bosses attempt to walk a mile in their workers' shoes. Critics think the ploy superficial and a marketing ruse for the companies involved; but it has received plaudits noting that it provides a timely reminder of the value of empathy and genuine management caring. Just this year New Zealand was reminded of this by EEO Commissioner, Judy McGregor, as she reported on a week undercover as a frontline aged care worker: "if you haven't done it, you don't get it...to do is to know. To know is to get angry” (Human Rights Commission, 2012: 127, 132). As a result McGregor understood the work conditions, lack of training opportunities, meagre pay and yet emotional commitment of these workers in a way that made her passionately angry on their behalf - she cared about their plight. Clearly empathy can change one's views and subsequent actions. But, aside from these public examples, how much do we know about managerial empathy and its impact on management practices? As this paper will discuss, we know a little but not a lot.

Plenty of research, old and new, international and local, confirms that management matters in organisations (Bloom \& van Reenen, 2010; Green, Argawal et al, 2011; Ryan, 2008). Managers and their practices impact on performance and productivity of individuals, workgroups and organisations. In this regard the broader management, employment relations and organisational literature attends to issues ranging from business strategy to managing employee engagement and organisational culture. However, other than a flurry of activity around emotional intelligence (see Goleman, 1996), there has been very little research on managerial empathy. For instance there is no good explanation of why and when managers (or indeed anyone) display empathy, nor much exploration of the impact of management empathy for workers, customers, suppliers and other stakeholders.

So, what is empathy? Initially the preserve of moral philosophers reflecting on human behaviours and the qualities that underpin them, it was not long before the concept became a significant one in the psychology profession. From these beginnings empathy has become an everyday term and a desirable attribute, thus it is surprising how little it has featured in the management and organization literature. In the following, we trace the genesis of empathy in the English language, through its development in psychology and subsequent usage in management-related literatures. We then report a selection of examples showing the impact of managerial empathy in several New Zealand organisations, and implications for future research.

\section{The origins and main strands of meaning in empathy}

In 1909 Edward Titchener coined the English language term 'empathy' as a translation of German philosopher Theodor Lipps concept of 'einfuhhlung' (Katz, 1963; Davis, 1996). Lipps was describing aesthetic appreciation, that state when an observer of a piece of art loses self-awareness and becomes absorbed in the art, literally 'feels into' the art. For Lipps this was a process of the imagination and unconscious projection of the self into the object (Katz, 1963).

Core debates in meaning. The concept of empathy continued to develop throughout the twentieth century, 
largely debated by psychologists. The debates varied but mainly centered on two strands of meaning in empathy. One stresses the importance of role or perspective taking, that is, imagining yourself in the others situation in order to understand it. The other strand emphasizes the engagement of emotion, that is, not only to understand the others' situation but also to feel it. Davis (1996) refers to these meanings as two separate phenomena: 'cognitive role taking' and 'affective reactivity'. The psychology literature is divided over the importance that should be accorded to either or both of these meanings (Davis, 1996). In addition Davis notes "there has been a longterm confusion between empathy as process and empathy as outcome" (1996: 9). Discussions of cognitive role taking are more frequently viewed to be displaying empathy as process (for instance, I empathize with you by the cognitive act of adopting your perspective), whereas affective reactivity definitions are focused on achieving an affective response or outcome (for instance, I empathize in order to feel what you feel). Davis reports that Hogan (1969) adds another dimension to this debate. As one who was very much in the 'cognitive role taking' camp, he regarded empathy as understanding another's situation but without having to experience that person's feelings. However, he saw these as both process and outcome: the empathy process was role taking and the outcome was comprehension. These assumptions underpin Hogan's widely used empathy measure (the EM scale).

Empathy and social functioning. Katz (1963: 3) observes that "sometimes we directly ask the other person to empathize with us, as when we ask, 'what would you do if you were me?'”. Empathy is an accepted part of social functioning that helps us to give appropriate reactions to others' situations and to anticipate the reactions of others to our own behavior. Indeed, the 1930s developmental psychologist, Piaget, and social psychologist, Mead, both observed the importance of 'role taking' and abandonment of a purely selfish perspective as a vital part of social development and social existence. Overall, there is general agreement in the psychology literature that empathy significantly and desirably influences social behavior and relationships, although at times empathyinduced altruism may privilege an individual beneficiary relative to the collective good (Batson et al., 1995a, 1995b).

Empathy as professional tool. Psychotherapy and counseling pioneered the professional use of empathy as a tool to assist understanding of, and working with, clients. In this regard the therapist empathizes with the client not only to understand them, but also to facilitate the therapeutic relationship through the use of empathetic listening which demonstrates attention, care and understanding. This understanding and demonstration of it starts to build trust in the relationship. This is epitomized in person-centered theory advanced by psychologist Carl Rogers (1961) as a humanistic alternative to psychoanalytic approaches to therapy. He believed that three conditions must be present for a therapeutic relationship to succeed: genuineness, acceptance, and a sensitive empathy (a deep empathetic understanding which enables one to see the world through the client's eyes).

\section{Empathy in management-related literature}

As described above, empathy sounds like an eminently useful and admirable quality for a manager to possess so what do the management and organizational literatures contribute to understanding this concept?. Occasional strands of organization-related literature acknowledge that looking beyond ourselves and our own interests, or desires, to the needs of others is important to long-term success or wellbeing. For example, almost 60 years ago Speroff (1953) argued that empathy presents a possible "key" for bringing about more effective labormanagement relations. Most recently Lilius et al (2011) theorised compassion in a work unit and subsequently called for organizational scholars to explore emotionbased capabilities in the workplace. There is, thus, an implicit (and infrequently explicit) appeal to empathy, expressed at times in the marketing, human resource management (HRM), strategic management and business ethics literature.

Marketing and empathy. In the marketing literature as early as Levitt (1960) there was an appeal to consider what the market needs, rather than impose the products and services the company wants to sell. More recently, McBane (1995) demonstrates that empathy will improve salesperson performance. Drawing on psychology he provides a three dimensional view of empathy as perspective taking, empathetic concern and a third component 'emotional contagion'. Emotional contagion, or having an emotional experience parallel to the other person's actual emotions, would appear to be a more dramatic term for 'affective reactivity' as was discussed above. Bagozzi (2006) also looks at salesperson and customer behavior, and notes that empathy can facilitate communication and information processing, and that it can moderate the effect of guilt in repairing damaged customer relationships.

HRM and empathy. With its human focus and closer ties to psychology, one would think the HRM literature provides a natural home for empathy. However, that is not the case and significant tensions are reported for HR practitioners in balancing strategic HRM and employee well-being (Brown et al., 2009). The HR practitioner has at times conflicting roles (or stakeholders) - one management-centered and the other employee-centered. These tensions focus on the potential loss of caring and empathy with employees in order to favor organizational goals. Ulrich and Brockbank (2005) argue that HRM value is defined by the receivers of HR service and so, in an extended but implicit appeal to empathy, they argue that as a result practitioners need to think like their stakeholders. Mencl and May (2009) examined the impact of empathy on the ethical decision making of HR professionals and found that those who could take other's perspectives and feel compassion made more informed and ethical decisions. Karnes' (2009) research, examining the impact on employer-employee relations of changing business ethics since the 1940s, shows that lack of leadership plays a significant role in the disintegration of employment relationships and concludes that organizations under-train and under-develop empathy and social skills. These are regarded as vital for building and 
managing relationships, finding common ground and building rapport (Karnes, 2009).

Strategy, business ethics and empathy. In the strategy literature one would expect the richest vein of empathyrelated thinking to be in stakeholder theory perspectives. After all, popular appeals to 'triple bottom line' (Elkington, 1997) portray corporate leaders as accountable to their broader stakeholders not just their shareholders. However, this literature is relatively silent on empathy. A study by Agle et al. (1999) includes compassion/empathy as one item in their CEO values scale - however, their objective was to assess self-interest vs. other regarding values broadly across all stakeholders rather than considering if empathy might differ for specific stakeholders. More frequently, explicit discussions of empathy are to be found in the business ethics literature. For example, managerial empathy can contribute to stakeholder satisfaction and trust (Strong et al., 2001); and to ethical decision making (Mencl and May, 2009). Similarly, Cohen (2010) contrasts empathy (putting oneself in a counterpart's shoes) with perspective taking and finds that empathy is more likely to deter unethical bargaining. Empathy is described as "a positive moral emotion that aids reasoning (Pizarro, 2000; Pizarro and Salovey, 2002) and promotes interpersonal relationships (Hoffman, 1990; Tangney, 1991)" (Mencl and May, 2009: 202). Through confirmatory factor analysis, Chun (2005) identifies empathy as one of six dimensions of organizational virtue along with integrity, warmth, courage, conscientiousness and zeal. Empathy is also noted peripherally in arguing the distinction between stewardship and altruism or organizational citizenship behaviors (Hernandez, 2012), and within the economic literature there are references to the impact of empathy on managerial decision making (Stark and Falk, 1998; Zsolnai, 1997), in particular noting that responsible decision makers display social commitment and empathy.

Leadership and empathy. The recent burgeoning of research around emotion in organizations has given rise to new perspectives on decision making, leadership, learning, resistance, and the management of worker emotion (Bolton, 2000; Fineman, 2006), but has not dealt with empathy in any detail. The only area in which empathy has had renewed attention has been with the somewhat controversial popularization of the concept of emotional intelligence (Goleman, 1996). In earlier academic work on this concept, Salovey and Mayer (1990) claim: "empathy may be a central characteristic of emotionally intelligent behavior” (p.195). They note that empathy can determine the credibility and acceptability of advice, and motivate altruistic behavior. They regard empathy as including a feeling for others, sympathetic reactions to their feelings and imaginative involvement in how the other person might be feeling. Certainly, although not always labeled as teaching empathetic tools, it is not unusual for leadership and management training to include instruction on active listening techniques (Bolton, 1986; Covey, 1990; Gentry et al., 2010). These are popular for assisting managers in encouraging staff input, conducting difficult conversations, giving feedback, and seeking more disclosure from an interviewee.
Overall, it can be seen that there are, across these various literatures, two recognized aspects of empathy: perspective taking (cognitive) and putting oneself in another's shoes to the extent of experiencing similar feelings (affective). Additionally, empathy appears uniformly regarded as important for social functioning, in particular the building and managing of relationships.

\section{Do managers care in New Zealand organisations?}

Following on from this, we present examples of managerial empathy which changed who managers cared about as well as how they cared. These examples arose from a series of case studies based on interviews (focusing broadly on strategy and productivity) with senior managers in 10 manufacturing companies in the food and beverage sector in New Zealand. These companies were chosen based on whether they were perceived to have medium or high relative levels of productivity. Multiple interviews, by a team of researchers with varying organizational perspectives, were undertaken with every Chief Executive and different functional managers in the 10 companies. In each organization, these interviews addressed the full range of current business activities and occurred in 2009-2010 while the New Zealand economy was still in recession. All 28 interviews were digitally recorded and fully transcribed, varying in length from 45-90 minutes. We use a few of these examples in the following section to illustrate how empathy was exhibited in these cases and at times, contrast them with parallel situations where empathy was not apparent. We examine managerial empathy for 4 different stakeholder groups: potential workers, actual workers, suppliers and customers. We comment on the observed impact of managerial empathy for these groups particularly in terms of increasing their apparent salience or importance to the organisation.

\section{Examples of managerial empathy with workers}

Our first example explores empathy for an often overlooked group - potential workers - that is people in the labour market whom the organization regards as suitable to attract to a position. It is not difficult to imagine situations where potential workers attract management attention just by virtue of possessing skills which are in short supply and highly sought after by an organization, such as key scientists or managers with extensive alliance experience. In other instances, for example when information technology specialists (or others) are needed for a project that cannot be delayed, urgency may also be added into that mix increasing the status of these key potential workers. In our examples, however, the potential employees were not highly skilled, did not command high wages, were not necessarily in short supply, and the jobs they filled were semi-skilled processing roles in agriculture-related industries. In fact, these potential workers often came from unemployment, could be unreliable in terms of attendance at work, and could choose to have very short tenure in the organization since the jobs were often strenuous or involved tasks that are perceived by many as unpleasant. Patchy attendance 
and high staff turnover created extra costs for such organizations with most of the companies we studied just putting up with this issue as a 'cost of business'.

However, two companies had taken a different approach to their potential workers. In one, a senior manager had thought: "what would make life good to work here?”. By imagining himself in the shoes of a potential employee he realized that "It's a hard place to get to [the factory] if you're unemployed or live in $\mathrm{X}$ [no transport links between $\mathrm{X}$ and the factory]". As a result the organization introduced a free bus service to and from the workplace.

In the other company the owner had also thought about the life circumstances and needs of the potential labour pool. He had then tailored the work terms and conditions to meet those needs. Specifically, in work that could not be done when it was raining, he had provided continuity of income through a weekly base level of pay regardless of weather. "You have to understand - what are these people doing? How do they survive in the world? You've got to understand that these people have got mortgages or rent to pay on their house, HP [hire purchase] payments on their television or whatever, so they have to make enough money to do that. If, because of the weather, you haven't got any work for a week, what's that person going to do? So we've guaranteed a minimum [income]".

These are both examples of situations in which most similar companies would disregard these potential workers as unimportant. In both companies a manager empathized with the potential workers by taking their perspective, and by really understanding why one would not stay in the job, or would be late to work, or not want to be bothered with the work required. This clearly involved the process and outcome of empathy - cognitive role taking and comprehension of the others' situation and the feelings it evokes. The outcome of this managerial empathy resulted in new business strategies (such as pay systems, transport arrangements) because the process of empathizing changed the salience of the potential stakeholders. The managerial empathy had the effect of making these people more important such that the organizations reshaped their practices and developed new enhanced relationships with such stakeholders giving them more voice and rights.

The psychology literature maintains that empathy is important to the building and managing of relationships (Katz, 1963) and it has been linked to altruistic motivations to increase another person's welfare (Batson, 1995). Hence, it would seem reasonable to expect that empathy might be shown towards current employees thus impacting their salience. We have various examples of other managers beyond the two instances above attempting to bring empathetic understanding to employee situations:

"We understand people's personal situations... and support them accordingly."

"Every day, I spend an hour in the factory talking to everyone - how's it going, issues, etc.”

"We encourage them to have a voice in the organization to express ideas, concerns, [...]”
"We invest in training for staff so that people build skills and confidence and feel like they are developing [...]. We never set someone up to fail.”

In these cases, this too increased the legitimacy of workers as stakeholders resulting in changes of practice and if unique skills were developed that are valuable to the organization then these employees' power may also increase.

On the other hand, there were organizations that did not regard workers as important stakeholders, or accorded them little attention relative to other priorities. As one human resources manager commented to us "I am embarrassed by staff churn [turnover ...] we need to care more about staff”. However, that manager's own lack of salience on the management team made it difficult to effect any change in practice. This management team paid little heed to staff turnover, nor made any connection to negative impacts on the business, as the demand for their manufactured goods remained high and even with high turnover they were able to keep up with demand. Thus, this suggests that to be without empathy results in a devaluing of those relationships and a consequent lack of care for that stakeholder group.

\section{Empathy for a supplier or a customer}

In another example, a small firm that had competed successfully against large multinationals in a line of confectionery products was faced with a requirement for traceability of all aspects of its supply chain. This demand had been placed on it in order to obtain sales with large UK supermarket chains and the General Manager notes: "If you don't have a HACCP [hazard analysis critical control point] quality system in place, the supermarkets don't want to deal with you. So HACCP was the first thing we got and then we thought, no, we want to aim for higher. So then we went for BRC [global standards]. [...] BRC takes it a step further. You've got to have traceability of all of your primary and secondary packaging as well." "We actually had a meeting this morning with one of our [...] suppliers just to explain what was required in terms of a certificate analysis, for example, that we have to have with everything that comes in. But it's working together. They're actually going through a HACCP implementation themselves. So it's good, because they're learning and they're able to ask us questions." This example illustrates different approaches to supplier relationships, with the supermarkets simply passing on requirements to manufacturers to meet on their own, whereas in this case the manufacturer sought to extend a relationship through helping and guidance, "working together", even though other qualified suppliers could likely have been found. Having been through the HACCP process recently themselves facilitated their collaborative and supportive approach with their smaller local supplier.

We have witnessed other examples of increased salience of a stakeholder due to the empathetic role-taking and genuine understanding by managers. In such organizations, the managers expressed an understanding that stakeholders trust you, your organization and your product or service if it is predictable, that is, of consistent 
quality. In most cases the foundation for ensuring such consistent quality lay in the building and managing of relationships (with employees, suppliers, distributors, retailers, consumers, competitors, the industry and region).

Furthermore, even in the case of very powerful stakeholders we found examples of managerial empathy which influence choice of business practices/strategizing in relation to these stakeholders. One company described to us their efforts to understand the business and longterm interests of their suppliers and to enhance understanding of each other, with the end result being that "we are transparent in the deals we offer them". This is a small example where empathy with a key stakeholder underpinned a more co-operative advantage model of business. We observed similar models emerging with key retailers. Two companies reported that "overseas customers like to deal with us, not some distributor, so we see them three or four times a year". This, they report, enables the manager to understand what the retailer wants, how to add value to the product and the service, and "to build personal relationships in order to understand their businesses and needs, to increase responsiveness". Displaying empathy with customers is probably viewed as simply good business practice by most, but managers can display significant variations in the ways in which they address customers' needs. While some manufacturers focus on achieving the greatest sales for their existing products and processes, others perceive their role as one to "make [their customer's] product more valuable to the end consumer, who will pay more - [that is,] poke more into the top of the value chain and let it flow down through."

Given the potential benefits arising from such empathetic approaches, one might suggest that to be without empathy is to risk being completely out of touch with one's stakeholders. However, a key aspect in these instances of managerial empathy appears to be the pursuit and realization of enhanced value creation. Thus, without potential for joint value creation or if the stakeholder is unlikely to adopt a co-operative stance, then engaging empathetically may be unproductive, futile or even naïve if the company risks losses from such actions. This was clearly exhibited in situations where the managers who empathized with one set of stakeholders, concurrently disregarded or only sympathized with the claims on them, objectives or values of other stakeholders. Empathy, then, appears to be exhibited selectively and may not be a characteristic affecting all stakeholder relationships that a particular manager or management team may engage in.

\section{Implications for future research}

As highlighted in the examples above, empathy appears to moderate the manager-stakeholder relationship by changing manager's perceptions of the stakeholder. In particular, the process of empathizing raises a stakeholder's salience or importance - they are visible and catered for by the organisation. Any manager faced with a business issue or dilemma may sympathize with or acknowledge stakeholder circumstances, but those who empathize engage in a deeper understanding of the situation and the feelings it evokes. This more thorough comprehension serves to thus legitimate (or sometimes de-legitimate) the stakeholder and their circumstances and may help bring joint value creation possibilities to the forefront. For instance, the apparently lazy and selfindulgent potential employee, current supplier, retailer, or worker can, when empathized with, prove instead to be fearful, stressed, lacking in confidence, or too busy, inefficiently used, even underutilized - all circumstances for which changes in business practice can make it easier to meet their needs and yours. While one must allow that for some instances the superficial interpretation of laziness was in fact the correct one, this too may alter business strategy; for instance, changing the level of reliance on that stakeholder or withdrawing all business from them.

Hence, empathy also changes how managers care about the stakeholder, that is, it results in changes to business practices and strategizing. Changes from such empathetic processes are, of course, ultimately beneficial to the business, but generally because they have their genesis in empathetic understanding, they tend to offer mutual benefit to the organization and the stakeholder. In this regard, the exercise of managerial empathy facilitates the path to a business model based on more co-operative advantage and developing and maintaining longer-term relationships.

However, as an additional observation, we believe that an empathetic manager's own salience to the management team will also be an important mediating factor in the success of being able to change business practices to show more care and compassion. As in all management team or board room decisions, many factors influence whether a proposed strategy or practice is deemed acceptable. A lone manager exhibiting empathy in a team of less empathetic individuals may find it hard to get support for changes that benefit a stakeholder. Thus, in practice, the extent to which empathetic strategies are implemented will likely be lower than the extent to which managers individually display empathy. The unanswered conundrum raised by this research is what leads managers to empathise?

\section{References}

Agle BR, Mitchell RK and Sonnenfeld JA (1999) Who matters to CEOs? An investigation of stakeholder attributes and salience, corporate performance, and CEO values. Academy of Management Journal 42(5): 507-525.

Bagozzi R (2006) The role of social and self-conscious emotions in the regulation of business-to-business relationships in salesperson-customer interactions. Journal of Business \& Industrial Marketing 21(7): 453-457.

Batson CD (1995) Prosocial motivation: Why do we help others?. In: Tesser A (ed) Advanced social psychology. New York, NY: McGraw Hill.

Batson CD, Batson JG, Todd RM, Brummett BH, Shaw LL and Aldeguer CMR (1995a) Empathy 
and the collective good: Caring for one of the others in a social dilemma. Journal of Personality and Social Psychology 68: 619-631.

Batson CD, Klein TR, Highberger $L$ and Shaw LL (1995b) Immorality from empathy-induced altruism: When compassion and justice conflict. Journal of Personality and Social Psychology 68: 1042-1054.

Bloom N and Van Reenen J (2010) Why do management practices differ across firms and countries? Journal of Economic Perspectives 24(1): 203-224

Bolton R (1986) People Skills. Englewood Cliffs, NJ: Prentice Hall.

Bolton S (2000) Emotion here, emotion there, emotional organisations everywhere. Critical perspectives on Accounting 11: 155-171.

Brown M, Metz I, Cregan C and Kulik C (2009) Irreconcilable differences? Strategic human resource management and employee well-being. Asia Pacific Journal of Human Resources 47(3): 270-294.

Chun R (2005) Ethical character and virtue of organizations: an empirical assessment and strategic implications. Journal of Business Ethics 57: 269-284.

Cohen TR (2010) Moral emotions and unethical bargaining: The differential effects of empathy and perspective taking in deterring deceitful negotiation. Journal of Business Ethics 94(4): 569579.

Covey S (1990) The seven habits of highly effective people: restoring the character ethic. New York, NY: Free Press

Davis MH (1996) Empathy: A social psychological approach. Boulder, Co: Westview Press.

Elkington J (1997) Cannibals with forks: the triple bottom line of $21^{\text {st }}$ century business. Oxford: Capstone.

Fineman S (2006) Emotion and organizing. In Clegg S and Hardy C (eds) Handbook of Organization Studies, $2^{\text {nd }}$ edition. London: Sage.

Gentry W, Weber T and Sadri G (2010) Empathy in the workplace. Available at: http://www.ccl.org/leadership/pdf/research/Empat hyInTheWorkplace.pdf. Greensboro, NC: Center for Creative Leadership.

Goleman D (1996) Emotional Intelligence: Why it can matter more than IQ. London: Bloomsbury.

Green R, Argawal R (2011) Management matters in New Zealand: how does manufacturing measure up? Ministry of Economic Development Occasional paper 11/03. Wellington: Ministry of Economic Development.
Human Rights Commission (2012) Caring Counts: Report of the Inquiry into the Aged Care Workforce. Wellington, NZ.

Karnes R (2009) A change in business ethics: the impact on employer-employee relations. Journal of Business Ethics 87: 189-197.

Katz RL (1963) Empathy: Its nature and uses. New York, NY: The Free Press of Glencoe.

Levitt T (1960) Marketing myopia. Harvard Business Review 38(4): 45-56.

Lilius JM, Worline MC, Dutton JE, Kanov JM and Maitlis S (2011) Understanding compassion capability. Human Relations 64(7): 873-899.

McBane D (1995) Empathy and the salesperson: a multidimensional perspective. Psychology and Marketing 12(4): 349-370.

Mencl J and May D (2009) The effects of proximity and empathy on ethical decision-making: an exploratory investigation. Journal of Business Ethics 85(2): 201-226.

Mitchell RK, Agle BR, Wood DJ (1997) Toward a theory of stakeholder identification and salience: defining the principle of who and what really counts. Academy of Management Review 22(4): 853-886.

Rogers C (1961) On becoming a person: A therapist's view of psychotherapy. Boston, MA: Houghton Mifflin.

Ryan R (2008) Why workplaces matter: the role of workplace practices in economic transformation. Wellington: Department of Labour.

Salovey P and Mayer J (1990) Emotional intelligence. Imagination, Cognition and Personality 9: 185211.

Speroff BJ (1953) Empathy and role reversal as factors in industrial harmony. Journal of Social Psychology 37: 117-120.

Stark O and Falk I (1998) On the economics of giving: transfers, empathy formation, and reverse transfers. The American Economic Review 88(2): 271-276.

Stovall O, Neill J and Perkins D (2004) Corporate governance, internal decision making and the invisible hand. Journal of Business Ethics 51(2): 221-227.

Strong K, Ringer R and Taylor S (2001) THE* rules of stakeholder satisfaction. Journal of Business Ethics 32(3): 219-230.

Ulrich D and Brockbank W (2005) The HR Value Proposition. Boston, MA: HBS Press.

Zsolnai L (1997) Moral responsibility and economic choice. International Journal of Social Economics 24(4): 355-363. 